\title{
PERANCANGAN DAN IMPLEMENTASI ASESMEN DIRI PADA MATA PELAJARAN TEKNIK PEMOGRAMAN DI KELAS TAV X SMK NEGERI 3 SINGARAJA
}

\author{
Putu Dharma Sanjaya, Nyoman Dantes, Ni Ketut Widiartini \\ Program Studi Penelitian dan Evaluasi Pendidikan, Program Pascasarjana \\ Universitas Pendidikan Ganesha \\ Singaraja, Indonesia
}

e-mail: \{dharma sanjaya, nyoman.dantes, ketut widiartini\}@pasca.undiksha.ac.id.

\begin{abstract}
Abstrak
Penelitian ini bertujuan untuk merancang dan mengimplementasikan asesmen diri pada mata pelajaran teknik pemograman di kelas $X$ jurusan teknik audio video (TAV) SMK Negeri 3 Singaraja, Kabupaten Buleleng, Provinsi Bali. Subyek penelitian berjumlah 58 orang siswa yang diambil dari 2 kelas X TAV yang ada, dengan rincian 1 kelas dari TAV 1 dengan 29 siswa dan TAV 2 dengan 29 siswa. Desain penelitian yang digunakan research and development dengan model 4-D (define, design, development, disseminate) yang dikenalkan oleh Thiagarajan Semmel. Dalam penelitian ini tahap disseminate tidak dibuat karena penelitian tidak dikembangkan pada skala yang lebih luas. Analisis data dilakukan dengan teknik deskriptif kuantitatif

Hasil penelitian didapatkan bahwa dalam tahap define terdiri dari angket kebutuhan guru akan asesmen diri pada mata pelajaran teknik pemograman dan analisisnya diperlukan dengan bentuk asesmen diri yang dibutuhkan adanya evaluasi sikap, adanya konsep diri, adanya tes tertulis, adanya persentasi, adanya kinerja kecakapan. Analisis silabus juga diperlukan asesmen diri pada setiap kompetensi dasar. Sedangkan pada tahap design terdiri dari revisi RPP dan perancangan ceklis yang bermuatan asesmen diri berdasarkan kurikulum 2013. Tahap development terdiri dari hasil uji lapangan dan analisis data. Diperoleh hasil Validasi tes berbasis asesmen diri meliputi: (a) Validitas isi sudah memenuhi syarat dengan melakukan melakukan uji judges menggunakan formula Gregory diperoleh validitas isi sebesar 1,00 artinya judges menyatakan instrumen relevan untuk diujicobakan. (b) validitas empirik instrumen menggunakan rumus korelasi point biserial dinyatakan sudah memenuhi syarat karena semua ketentuan yang harus ditempuh seperti; uji validitas butir yang sudah dilakukan seperti yang telah ditentukan. (3) Reliabilitas tes ceklis berdasarkan asesmen diri menggunakan rumus KR-20 dinyatakan sudah memenuhi syarat karena konsistensi atau keajegan tes masih terhitung tinggi.
\end{abstract}

Kata-kata Kunci : Asesmen Diri, Implementasi, Perancangan,, Teknik Pemograman.

\section{Abstract}

This study aims to design and implement self-assessment on the subjects of programming techniques in the class $X$ majoring in audio video engineering (TAV) SMK Negeri 3 Singaraja, Buleleng Regency, Bali Province. The research subject amounted to 58 students taken from 2 classes of existing TAV X, with details of 1 class from TAV 1 with 29 students and TAV 2 with 29 students. This research is a research and development research with 4-D model (define, design, development, disseminate) introduced by Thiagarajan Semmel. In this study, the disseminate were not made because research was not developed on a wider scale. Data analysis was done by quantitative descriptive technique.

The result of the research is that the define stage consists of questionnaire of teacher need for self assessment of programming technique and the result of self assessment form needed by attitude evaluation, self concept, the written test, the presentation, the performance of the skill. The syllabus analysis also requires selfassessment on each of the basic competencies. While the design stage consists of 
revision RPP and design of checklist that have self assessment based on the 2013 curriculum. . Based on the results of field tests and data analysis drawn conclusions as follows; (1) The checklist grading of self-assessment for programming technique subjects enables the creation of various checklist statements for each type of cognitive, affective, and psychomotor process. (2) Validation of self-assessment based tests includes: (a) Validity of contents is eligible by performing judgment test using Gregory formula obtained content validity of 1.00 means judges declare relevant instruments to be tested. (b) the empirical validity of the instrument using the biserial point correlation formula shall be declared eligible because of all the provisions that must be followed such as; test the validity of the item that has been done as specified. (3) The reliability of a check test based on self-assessment using KR-20 formula is considered to be eligible because consistency or t testability is still high.

Keywords: self assessment, implementation, Planning, technical progamming.

\section{PENDAHULUAN}

Pendidikan di Indonesia memulai
babak baru dengan diujicobakannya
Kurikulum 2013 di beberapa sekolah.
Tema yang diusung Kurikulum 2013
adalah dihasilkannya manusia Indonesia
yang produktif, kreatif, inovatif, afektif
melalui penguatan sikap, keterampilan,
dan pengetahuan yang terintegrasi. Untuk
itu, pada pelaksanaannya, digunakan
pendekatan scientific (Scientific Approach)
(Mulyasa, 2013). Di dalam proses
pembelajaran dengan Pendekatan
Scientific, terdapat proses mengamati
(Observing), bertanya (Questioning),
menalar (Associating), mencoba (Experimenting), menyimpulkan, dan membentuk jejaring (Networking). Pada pelaksanaannya, pendekatan scientific bisa dikombinasikan dengan beberapa model dan pendekatan berikut ini: pendekatan kontekstual, pendekatan berbasis masalah, pendekatan berbasis proyek, dan lain lain. Intinya, peserta didik dituntut untuk bisa menemukan dan mengkonstruksikan pengetahuannya sendiri, sedangkan guru berperan sebagai fasilitator yang membantu mengarahkan peserta didik. Dengan demikian, peserta didik diharapkan dapat menemukan sendiri konsep dari yang akan diajarkan. Proses pembelajaran yang diharapkan adalah yang kontekstual dan berpusat pada peserta didik (student centered active learning) (Rosidah, 2013). Selain digunakannya pendekatan scientific, pada implementasi kurikulum 2013 dituntut juga adanya penilaian yang autentik (Authentic Assessment).
Kebijaksanaan

pemerintah menggunakan Kurikulum 2013 didasarkan pada dan Peraturan Pemerintah No. 32 Tahun 2013 tentang perubahan atas Peraturan Pemerintah No. 19 tahun 2005, dan tentang Standar Nasional Pendidikan. Permendikbud No. 66 Tahun 2013 Tentang Standar penilaian menyebutkan bahwa Standar Penilaian Pendidikan adalah kriteria mengenai mekanisme, prosedur, dan instrumen penilaian hasil belajar peserta didik. Penilaian pendidikan sebagai proses pengumpulan dan pengolahan informasi untuk mengukur pencapaian hasil belajar peserta didik mencakup: penilaian otentik, ulangan, ulangan harian, ulangan tengah semester, ulangan akhir semester, ujian tingkat kompetensi, ujian mutu tingkat kompetensi, ujian nasional, dan ujian sekolah. Berdasarkan Permendikbud No.66 tahun 2013 bahwa Standar Penilaian Pendidikan bertujuan untuk menjamin: (1) Perencanaan penilaian peserta didik sesuai dengan kompetensi yang akan dicapai dan berdasarkan prinsip-prinsip penilaian, (2) Pelaksanaan penilaian peserta didik secara profesional, terbuka, edukatif, efektif, efisien, dan sesuai dengan konteks sosial budaya; dan (3) Pelaporan hasil penilaian peserta didik secara objektif, akuntabel, dan informatif. Namun dalam penjelasan tersebut belum dijelaskan secara operasional bagaimana guru melakukan penilaian.

Penilaian atau asesmen memiliki kedudukan yang sangat penting dalam pembelajaran karena asesmen memiliki fungsi yang strategis dalam pembelajaran. Fungsi asesmen sangat berkaitan dengan pengumpulan informasi, memproses dan 
menginterpretasikannya. Informasi tersebut dapat berupa latar belakang, sikap, tingkah laku, atau karekteristik yang dimiliki oleh individu, dengan kata lain asesmen ditunjukan untuk mendapatkan gambaran potensi dan kompetensi yang dimiliki oleh peserta didik. Asesmen memiliki fungsi keberpihak terhadap siswa khususnya dalam memajukan siswa sehingga siswa dapat mencapai kemajuan secara optimal (Wulan, 2007).

Menurut Airasian (1994) asesmen dapat dilakukan oleh seorang guru untuk tujuan pengambilan yang bervariasi, diantaranya adalah untuk mendiagnosis kesulitan belajar peserta didik, mengukur prestasi akademik peserta didik, memberikan umpan balik kepada peserta didik, penataan peserta didik di dalam kelas, mengaitkan perencanaan dan pelaksanaan tujuan instruksional. Pada umumnya sekolah hanya bisa melakukan asesmen melalui tes untuk mendeteksi hasil belajar peserta didik atau disebut tes prestasi belajar peserta didik. Purwanto (2008) mengemukakan bahwa tes hasil belajar adalah suatu alat evaluasi yang selama ini umum dipergunakan untuk menilai hasil-hasil pelajaran yang telah diberikan oleh guru kepada muridmuridnya. Penilaian autentik merupakan penilaian dengan pengukuran yang bermakna atas hasil belajar peserta didik. Penilaian autentik meliputi ranah sikap, keterampilan, dan pengetahuan. Beberapa jenis penilaian autentik yang ada yaitu asesmen kinerja, asesmen portofolio, asesmen proyek, dan asesmen diri (self assessment).

Selama ini asesmen yang sering dipakai di sekolah adalah asesmen kinerja, portofolio, proyek, sedangkan asesmen diri jarang dipakai. Peningkatan kualitas pembelajaran memerlukan upaya optimalisasi proses dan hasil belajar secara keseluruhan karena hakikat kualitas. Asesmen diri sebagai teknik penilaian akan sangat efektif untuk menggali nilai-nilai spiritual, moral, motif, sikap, bahkan aspek motorik dan kognitif peserta didik. Dengan teknik ini peserta didik diajak secara objektif untuk melihat ke dalam dan keadaan dirinya sendiri dengan jujur dan jernih. Dampak positif lain dari efektivitas teknik penilaian diri adalah peserta didik akan dikondisikan dan dibiasakan untuk selalu jujur. Dan jika anak selalu menjaga kondisi sikap dirinya ini sangat positif bagi upaya pembangunan karakter peserta didik. Peserta didik perlu memeriksa pekerjaan mereka dan memikirkan tentang apa yang terbaik untuk dilakukan dan area mana mereka perlu dibantu. Untuk menuntun peserta didik dalam memahami proses asesmen diri, guru perlu melengkapi mereka dengan lembaran asesmen diri. Tipe-tipe penilaian diri sendiri ini membagi tema yang umum, mereka meminta peserta didik menilai pekerjaannya untuk menentukan apa yang telah mereka pelajari, bagaimana mereka belajar, dan bagian mana yang masih tidak dimengerti

Teknik Pemograman merupakan salah satu mata pelajaran jurusan TAV di SMK Negeri 3 Singaraja yang cocok untuk diterapkan asesmen diri. Dalam Standar Isi Program Keahlian Teknik Audio Video mempunyai salah satu tujuan dari mata pelajaran teknik pemograman adalah memahami dan mempraktikan program aplikasi sederhana bahasa visual basic 2010 melalui percobaan, merancang dan merakit instrumen percobaan, mengumpulkan, mengolah dan menafsirkan data, serta mengkomunikasikan hasil percobaan secara lisan, tertulis, jujur dan berkarakter. Jadi dalam belajar Teknik Pemograman tidak cukup sekedar mengingat dan memahami konsep yang ditemukan dalam teori. Akan tetapi, yang sangat penting adalah pembiasaan karakter peserta didik. Pembelajaran visual basic dan penilaian hasil belajar visual basic harus memperhatikan karakteristik ilmu teknik pemograman sebagai produk dan proses. Misalnya, dengan melakukan percobaan di lab komputer untuk membuktikan kebenaran suatu teori. Penilaian yang sebenarnya adalah penilaian tentang kemajuan belajar siswa yang diperoleh sepanjang proses pembelajaran. Oleh karena itu penilaian tidak hanya dilakukan di akhir proses pembelajaran tetapi penilaian dilakukan selama proses belajar mengajar. Penilaian terhadap siswa harus memperhatikan tiga ranah yang perlu dinilai yaitu pengetahuan (kognitif), sikap 
(afektif), dan keterampilan (psikomotorik) (Sudjana, 1998).

Pada kenyataannya guru jarang sekali melakukan penilaian terhadap beberapa aspek, seperti aspek penilaian diri belajar peserta didik. Penilaian yang sering dilakukan oleh guru hanya penilaian kognitifnya saja sehingga seringkali tidak dapat memperlihatkan kemampuan peserta didik yang sesungguhnya. Di lapangan terungkap bahwa penilaian yang dilakukan selama ini baru mengukur penguasaan konsepnya saja itu pun hanya meliputi ranah kognitif yang rendah. Padahal pada perinsipnya penilaian harus bersifat menyeluruh (komprehensif), yang artinya harus menyangkut semua aspek kemampuan siswa yang meliputi kognitif, afektif dan psikomotor (Subekti \& Harry, 1986). Dalam melakukan penilaian kepada siswa tidak lah cukup dengan menilai hasil belajarnya saja, tetapi proses belajar juga perlu mendapat perhatian guru untuk mendapat penilaian terhadap siswa. Asesmen merupakan penilaian pada proses belajar maupun hasil belajar (Wulan, 2007). Berdasarkan hasil wawancara dengan guru bidang studi Teknik Pemograman di SMK Negeri 3 dapat dikatakan bahwa guru belum mengerti tentang asesmen diri pada kegiatan proses belajar mengajar karena tidak adanya sosialisasi tetang asesmen diri sehingga guru hanya melakukan penilaian asesmen kinerja dan portofolio (dokumentasi penulis,2017).

Hasil obsevasi juga menyebutkan bahwa ketika dilaksanakan kegiatan praktikum di lab computer, kinerja siswa kurang baik. Dalam satu kelompok, hanya sebagian peserta didik saja yang aktif selama kegiatan praktikum. peserta didik menganggap bahwa proses kegiatan praktikum tidak dinilai. Selain itu, cukup sulit bagi guru untuk menilai satu persatu kinerja yang dilakukan oleh tiap peserta didik. Penilaian kurang objektif karena tidak semua anggota dalam satu kelompok itu melakukan tugasnya, sehingga hasil belajar yang diperoleh pun tidak sesuai dengan kemampuan peserta didik. Selain itu guru juga tidak mempunyai instrument asesmen diri yang bagus untuk diterapkan selama praktikum berlangsung.

Sehingga Berdasarkan isu permasalahan di atas menyatakan bahwa dibutuhkan penilaian dengan asesmen diri. maka peneliti akan melakukan penelitian dengan judul: "PERANCANGAN DAN IMPLEMENTASI ASESMEN DIRI PADA MATA PELAJARAN TEKNIK PEMOGRAMAN DI KELAS $X$ TAV SMK NEGERI 3 SINGARAJA".

\section{METODE}

Penelitian ini dirancang untuk mengembangkan instrumen asesmen diri yaitu dengan menggali, memperluas dan meningkatkan kualitas instrument. Maka penelitian ini dirancang dalam wujud penelitian dan pengembangan (research and development) dengan model 4-D yang dikembangkan oleh S. Thiagarajan, Dorotthy S. Semmel, dan Melvyn I. Semmel (1974) (dalam Trianto, 2010). Model pengembangan ini terdiri dari 4 tahap utama yaitu: (1) define (pendifinisian), (2) design (perancangan), (3) develop (pengembangan), dan (4) disseminate (penyebaran). Akan tetapi dalam penelitian ini hanya menggunakan define (pendifinisian), design (perancangan), dan develop (pengembangan) dan tidak menggunakan disseminate (penyebaran) karena dalam penelitian ini tidak dikembangkan pada skala yang lebih luas, baik di kelas lain, sekolah lain, maupun oleh guru lain.

Analisis content untuk mengetahui validitas isi instrument yang dirancang menggunakan persamaan Gregory. Dalam penelitian ini, peneliti menggunakan rumus korelasi point biserial $\left(\mathrm{r}_{\mathrm{pbis}}\right)$. Korelasi point biserial $\left(\mathrm{r}_{\text {pbis }}\right)$ digunakan untuk mengukur validitas data yang bersifat dikotomi (hanya ada dua kemungkinan jawaban). Sedangkan Reliabilitas dalam penelitian ini menggunakan reliabilitas internal konsistensi dengan teknik Kuder Richardson (KR-20) karena bentuk pertanyaan hanya terdiri atas dua pilihan jawaban (dikotomi), 


\section{HASIL DAN PEMBAHASAN}

Hasil penelitian pada tahap define terdapat 2 hasil yaitu analisis kebutuhan guru dan analisis konsep berupa analisis silabus. Berdasarkan hasil analisis kebutuhan guru akan asesmen diri dalam mata pelajaran Teknik Pemograman dapat dijabarkan untuk responden pertama guru membutuhkan akan asesmen diri dalam pembelajaran Teknik Pemograman, hal ini dapat dilihat dari 3 butir peryataan, guru menyatakan membutuhkan akan asesmen diri pada tiap-tiap kompetensi dasar yang terdapat pada semester I (satu) untuk mata pelajaran Teknik Pemograman, begitu pula dengan responden kedua. Sehingga ditentukan bentuk asesmen diri mata pelajaran Teknik Pemograman antara lain : 1.Adanya evaluasi sikap,2 Adanya konsep diri, 3.Adanya tes tertulis, 4. Adanya persentasi, 5. Adanya kinerja kecakapan. ndikator pengembangan instrumen asesmen diri

Dalam tahap design Tahap Pertama Dalam penelitian didapat formatformat bahan ajar yang ada Jurusan TAV mata pelajaran teknik pemograman berupa Silabus, RPP, Materi visual basic dan lembar penelian sehingga nantinya format ini yang akan dikembangkan menjadi acuan untuk membuat asesmen diri. Tahap kedua dalam silabus terdapat 2 kompentensi dasar yaitu Kompetensi Dasar 3.1 Pengenalan Sejarah lingkungan pengembangan terintergrasi (Intergrated Development Enviroment - IDE) Bahasa Visual Basic dan kesuksesan seorang programmer dan Kompetensi Dasar 4.1 Instalasi visual basic dan pengenalan lingkungan visual basic 6.0. dari kedua KD tersebut dapat digunakan untuk membuat kisi-kisi instrument dari rumusan tujuan pembelajaran. Tahap Ketiga yang didapatkan hasil revisi RPP mata pelajaran teknik pemograman. Dimana sebelumnya belum terdapat asesmen diri sehingga setelah direvisi sudah dicantumkan hal-hal yang bermuatan asesmen diri untuk mendukung pembuatan ceklis asesmen diri. . Tahap Keempat Merancang rancangan awal kisi - kisi instrumen asesmen diri berdasarkan perumusan tujuan pembelajaran. Dalam hal ini penilian dalam ceklis dilakukan pada aspek kognitif, afektif dan psikomotor yang kemudian dikembangkan sesuai dengan standar kompetensi pada mata pelajaran teknik pemograman. Tahap kelima setelah membuat kisi - kisi instrumen langkah selanjutnya membuat ceklis asesmen diri mata pelajaran teknik pemograman kurikulum 2013 yang mengacu teori dan rumusan tujuan pembelajaran.

Tahap development didapatkan hasil uji validasi oleh 2 orang judjes yaitu 1. Prof. Dr. Anak Agung Ngurah Marhaeni. Dan 2. Prof. Dr, Ni Ketut Suarni. M.S.Kons. kedua dosen tersebut memiliki kualifikasi pengetahuan dibidang asesmen. Dari hasil pengujian oleh dua orang ahli dan analisis data tentang relevansi indikator dengan item yang terdapat dalam daftar penilaian asesmen diri pada mata pelajaran teknik pemograman yang dapat dilihat pada lampiran 10 halaman 164. berdasarkan analisis data dengan menggunakan formula Gregory diperoleh koefisien validitas isi sebesar 1,00 termasuk katagori sangat tinggi, yang artinya butirbutir instrumen menurut ahli sudah sangat releva. Langkah selanjutnya dilakukan revisi setelah proses validasi ahli dari dosen yang berkompetensi dibidang asesmen. Dalam uji ahli ada perbaikan yang harus dilakukan. Hasil masukan dan perbaikan dibuat pada instrumen dan diperiksa kembali oleh 2 dosen tersebut dan jika sudah dianggap benar maka instrumen bisa dilanjutkan ke uji cobaUji coba terbatas dilaksanakan terhadap peserta didik kelas $X$ TAV SMK N 3 Singaraja sebanyak 2 kelas. Validitas Emperik atau Concurrent validity dalam penelitian ini dianalisis dengan menggunakan teknik korelasi Point biserial (Candiasa :2010). Data yang didapat nantinya akan diolah menggunakan program excel 2010. Data hasil uji coba instrumen yang dilakukan oleh guru terhadap 58 orang dengan total peryataan ceklis sebanyak 16 soal yang dibagi 2 kelompok ceklis diperoleh hasilnya semuanya valid dan realiabel. hasil analisis uji validitas empiris tes instrumen yang menggunakan korelasi point biserial diperoleh $r_{p b i}$ semua ceklis diatas 0.300 sehingga dapat 
diinterprestasikan tes tersebut berada diatas $r$ tabel dengan katagori valid. Sedangkan reabilitas berada diatas 0.800 yang reabilitas masuk kategori sangat tinggi. Dengan mempertimbangkan hasil analisis ini maka instrument tersebut yang telah dikembangkan tetap di pertahankan. Artinya kisi-kisi instrumen yang dikembangkan tetap sama dengan kisi-kisi sebelum di uji cobakan

Produk akhir berupa ceklis asesmen diri dan booklet asesmen diri. Dalam ceklis dan booklet asesmen diri ada beberapa hal yang perlu dipertimbangkan antara lain: (1) aspek bahasa, teori dan langkah asesmen diri yang akan dinilai, urutan langkah kerja yang akan dinilai, menetapkan skala penilaian dan (2) meminta pertimbangan pakar atau ahli tentang langkah-langkah perancangan ceklis penilaian dalam bentuk asesmen diri

\section{Pembahasannya Menurut}

Marhaeni (artikel) menyebutkan Untuk langkah pertama, yaitu menentukan kriteria penilaian. Pengajar mengajak peserta didik bersama-sama menetapkan kriteria penilaian. Pertemuan dalam bentuk sosialisasi tujuan pembelajaran dan curah pendapat sangat tepat dilakukan. Kriteria ini dilengkapi dengan bagaimana cara mencapainya. Dengan kata lain, kriteria penilaian adalah produknya, sedangkan proses mencapai kriteria tersebut dipantau dengan menggunakan ceklis evaluasi diri. Cara mengembangkan kriteria penilaian sama dengan mengembangkan rubrik penilaian dalam asesmen kinerja. Ceklis evaluasi diri dikembangkan berdasarkan hakikat tujuan tersebut dan bagaimana mencapainya.

Penilaian diri dapat dilakukan dengan menggunakan daftar cek. Dengan menggunakan daftar cek, peserta didik mendapat nilai apabila kriteria penguasaan kemampuan tertentu dapat diamati oleh penilai. Jika tidak dapat diamati, peserta didik tidak memperoleh nilai. Ceklis telah diupayakan untuk disusun dengan sebaik-baiknya, tetapi kita sadari bahwa tidak mungkin ceklis yang tersusun itu merupakan suatu yang sempurna.
Implikasi hasil penelitian ini
diharapkan sumbangan yang bermanfaat terhadap guru mata pelajaran Teknik Pemograman, bahwa instrument penilaian berbasis asesmen diri dapat dipergunakan untuk melengkapi atau mitra penilaian proses dalam hasil belajar siswa, yang objektif dan dapat dipertanggung jawabkan terutama saat melaksanakan evaluasi terhadap hasil belajar siswa

Dengan adanya implementasi asesmen diri sebagai alat evaluasi, diharapkan tidak terdapat adanya kecemburuan untuk memberi nilai tinggi atau rendah tetapi memang benar-benar berdasarkan indikator-indikator pencapaian dalam ceklis instrumen yang sudah memiliki persyaratan validitas. Adanya pengembangan instrumen asesmen diri sebagai salah satu instrument alternative dalam proses dan produk pembelajaran, diharapkan dapat memberikan motivasi kepada para guru untuk mengembangkan sendiri jenis-jenis instrumen penilaian yang lain, baik dalam aspek kognitif, apektif maupun psikomotor. Maka dengan tersedianya instrumen penilaian berbasis asesmen diri ini dapat membantu guru

\section{UCAPAN TERIMAKASIH}

Penulis mengucapkan terima kasih kepada Prof. Dr. Nyoman Dantes selaku pembimbing I dan, Dr Ketut Widiartini, M.Pd selaku pembimbing II yang telah memberikan dukungan baik berupa pikiran maupun dukungan spiritual serta kepada seluruh pihak SMK Negeri 3 Singaraja atas kerjasamanya yang telah memberikan izin pada penulis untuk melaksanakan penelitian.

\section{DAFTAR RUJUKAN}

Arikunto, Suharsimi. 1997. Prosedur Penelitian Suatu Pendekatan Praktek. Jakarta: Rineka Cipta.

Agung dan Neni, L. 2011. Metode Penelitian. Bandung: ITB.

Agustian, Pran. 2014. Evaluasi Sistem Penilaian Hasil Belajar Pada Program Keahlian Mekatronika Di Sekolah Menengah Kejuruan Negeri Se-Kota Palembang Dalam 
Implementasi Kurikulum 2013.

Yogyakarta: Universitas Negeri

Yogyakarta.

Andrade, H. \& Du, Y. 2007. Student responses to criteria-referenced selfAssessment. Assessment and Evaluation in Higher Education. Washington D.C: APA.

Airasian, P.W. 1994. Classroom Assesment Second Edition. Singapore: Library of Congress Cataloging

Burhanudin Tola. 2006. Penilaian Diri. Jakarta: P3BP2Pusat Penilaian Pendidikan Badan Penelitian Dan Pengembangan Departemen Pendidikan Nasional

Budianto. 2010. Teori Belajar dan Implikasi dalam Pembelajaran, (Online), (http://edukasi.kompasiana.com/20 10/05/09/teori-belajar-dan implikasinya - dalam-pembelajarn), diakses 7 Februari 2018.

Black, P. \& Wiliam, D. 1998. Inside the black box: USA: Inpress

Brown B. 1993. Hematology: Principles and Procedures, 6thed. America: Lea \& Febiger.

Bustang. 2010. Pengembangan Perangkat Pembelajaran Matematika Berbahasa Inggris Berbasis Realistik pada SMP Rintisan Sekolah Bertaraf Internasional. Skripsi. Universitas Negeri Makassar

Boud. 1986. Enhancing Learning through Self Assessment. London: Kogan

Candiasa. 2010. Statistik Multivariat Disertai Aplikasi SPPS.

Singaraja: Undiksha.

Dantes, Nyoman. 2012. Metode Penelitian. Yogyakarta: Andi Yogyakarta

Dantes, Nyoman 2008. "Hakikat Asesmen Otentik Sebagai Penilaian Proses dan Produk dalam Pembelajaran yang Berbasis Kompetensi" (Makalah) Disajikan pada In House Traning (IHT) SMA Negeri 1 Kuta Utara, tanggal 22 Mei 2008.

Departemen Pendidikan Nasional, 2007. Kamus Besar Bahasa Indonesia. Jakarta: Balai Pustaka
Gino, H.J., Suwarni, Suripto, Maryanto dan Sutijan. 1998. Belajar dan Pembelajaran II. Surakarta: UNS Press

Gronlund, N. E. \& Linn, R. L. 1995. Measurement and evaluation in teaching. (6th ed.). New York: Publishing Company.

Kunandar. 2014. Penilaian Autentik (Penilaian Hasil Belajar Peserta Didik Berdasarkan Kurikulum 2013). Jakarta: Raja Grafindo Persada

Kerlinger, Fred N. 2000. Azas-azas Penelitian Behavioral. Yogyakarta: Gadjah Mada University Press

Koyan, Wayan. 2013. Asesmen dalam Pendidikan. Singaraja: Universitas Pendidikan Ganesha.

Kusuf, Weldan. 2013. Teknik Pemograman. Malang :PPPPTK BOE

Kemendikbud. 2013. Permendikbud No.66 tentang Standar Penilaian Pendidikan. Jakarta: Kementrian Pendidikan dan Kebudayaan

Marhaeni, A.A.I.N. 2005. Pengaruh Asesmen Portofolio dan Motivasi Berprestasi terhadap Kemampuan Menulis Bahasa Inggris (Disertasi). Jakarta: Universitas Negeri Jakarta.

Marhaeni, A.A.I.N. 2007. "Asesmen Otentik dalam Rangka KTSP Suatu Upaya Pemberdayaan Guru dan Siswa" (Makalah). Disajikan pada pelatihan KTSP bagi Guru SMP/MTs di Kabupaten Tabanan, tanggal 10-14 September 2007

Marhaeni, A. A. I. N. (2006). Menggunakan Asesmen Otentik dalam Pembelajaran. Makalah disampaikan dalam pelatihan pembelajaran bagi guru-guru SMA Negeri 1 Denpasar tanggal 19 Agustus 2006.

Marhaeni, A.A.I.N. 20013. Portofolio Dalam Pembelajaran. Suatu Pendekatan Asesmen Berbasis Kompetensi (Makalah). Singaraja: IKIP Negeri Singaraja.

Marhaeni, A. A. I. N. (2008). Tinjauan Teoritis Mengenai Asesmen 
Otentik dan Implementasinya dalam Pembelajaran. Makalah disampaikan dalam Seminar tentang Profesionalisme Guru dan Inovasi Pembelajaran.

Marhaeni, A.A.I.N. Marhaeni (2008). Asesmen Pembelajaran Tematik di SD Kelas Awal. Makalah disampaikan pada pelatihan guru Sd di Karangasesm: DBEP

Mulyasa, E. 2013. Pengembangan dan Implementasi Kurikulum 2013. Bandung: PT Remaja Rosdakarya

Mimin, Hariyati. 2008. Model dan teknik Penilaian Pada Tingkat Satuan Pendidikan. Jakarta: Gaung Persada Press

Orsmond,P. 2004. "Self and PeerAssessment: Guidance on Practice".

http://www.bioscience.heacademy. ac.uk (diakses 3 Maret 2016)

Rolheiser, C. \& Ross, J. A. 2005. Student Self-Evaluation: What Research Says and What Practice Shows. USA: Publishing Company

Roslinda, Nani. 2013. "Pelaksanaan Kurikulum 2013 dan Kendala". http://edukasi.kompasiana.com/20 13/11/30/pelaksanaankurikulum20 13dan-kendala-615487.html. (Diakses11 Agustus 2016)

Rosidah. 2013. Keefekifan Model Pembelajaran POGIL Berbantuan Lembar Kegiatan Peserta Didik Terhadap Kemampuan

Pemecahan Masalah. Semarang: Universitas Negeri Semarang.

Sugiyono. 2013. Metode Penelitian Pendidikan. Bandung : Alfabeta.

Setyosari, H. Punaji, Prof. Dr. M.Ed.2010. Metode Penelitian Pendidikan dan Pengembangan. Jakarta: Kencana.

Suwandi, Sarwiji. 2010. Model Assesmen Pembelajaran. Surakarta: Yuma Pustaka

Suhadi. 2007. Petunjuk Perangkat Pembelajaran. Surakarta: Universitas Muhammadiyah.

Sudjana, Nana. 2010. Penilaian Hasil Proses Belajar Mengajar. Bandung: Remaja Rosdakarya.
Trianto. 2007. Model-Model Pembelajaran Inovatif Berorientasi Konstruktivistik. Jakarta: Prestasi Pustaka Publisher.

Thiagarajan, S., Semmel, D. S \& Semmel, M. I. 1974. Instructional Development for Training Teachers of Expectional Children. Minneapolis, Minnesota: Leadership Training Institute/Special Education, University of Minnesota

Wilson, J. \& Wing Jan, L. 1998. Self assessment for students: proformas and guidelines. Melbourne: Victoria.

Wulan, A.R. 2007. "Pengertian dan esensi konsep evaluasi, asesmen, tes, dan pengukuran. http://file.upi.edu/direktori/fpmipa/ju rpendbiologi/anaratnawn /pengertian asesmen/pdf (diakses 7 Februari 2017)

Wina Sanjaya. 2006. Strategi Pembelajaran. Jakarta: Kencana Prenada

Zulharman. 2007. "Self and peer assesment sebagai penilaian formatif dan sumatif".http://zulharman79.wordpr ess.com/2007/05/29/self-danpeerasse ssment-sebagaipenilaian-formatif-dan-sumatif (diakses 24 Maret 2015) 